\title{
Feasibility of Nano clay and polypropylene aggregates in self compacting concrete.
}

\section{Kommisetti Komal1*, V.Swamy Srinath ${ }^{2}$}

${ }^{1} M$.Tech, Universal College of Engineering \& Technology, affiliated to JNTUK, Medikondur(M).

2Department of Civil Engineering, Universal College of Engineering \& Technology, affiliated to JNTUK, Medikondur(M).

*Corresponding author: KOMMISETTI KOMAL, Department of Civil Engineering Universal College of Engineering \& Technology, affiliated to JNTUK, Medikondur(M) ,Email: kommisettykomal@gmail.com

\section{Abstract}

The aim of this research was to investigate the rheological properties of Self-Compacting Concrete (SCC) using plastic waste as a partial replacement for sand and the fresh properties of SCC. For this purpose, SCC mixes with a constant water Cement ratio of 0.40 binder content have been created. Nano clay (NC) was used as a partial cement substitute (up 30 percent by weight of cement). A research topic was the contents of different sized plastic waste (polypropylene) Plastic waste (fine plastic waste). The compressive characteristics of self-compacting concrete were also tested after 28 days. The findings of the experiments show that the plastic waste and nano clay used in this analysis can be used as fine aggregate in SCC.

Keywords: Nano Clay (NC), Plastic Waste (Polypropylene), Rheological, Fresh Properties, Compressive Strengths, SelfCompacting Concrete (SCC).

\section{Introduction}

Self-compacting concrete (SCC) is a flowing concrete mixture that can consolidate under its own weight. The highly fluid nature of SCC makes it suitable for placing in difficult conditions and sections with congested reinforcement. The use of SCC can also help minimize hearing-related damages on the worksite that are induced by the vibration of concrete. Another advantage of SCC is that the time required to place large sections is considerably reduced. The concrete which having fluidity and consolidation with its own weight without any external vibration. It gets the homogeneous structure during the placing of concrete in framework. The self-compacting concrete easily flow throughout the reinforcement. Reduction of aggregate to get the friction and increasing the past content and fluidity properties.

SCC was used to precast application and placed on site. The SCC concrete manufacturing in the site batching plant or in ready mix concrete plants and delivered to the site by trucks.it can placed though the pumping into the horizontal or vertical structures.

\section{Experimental Programme}

\section{Materials}

The materials used to design the M30 grade of concrete mix are Cement, Nano clay, M-Sand, Polypropylene aggregate, Coarse aggregates, Admixtures, Water and Super Plasticizer. The properties of these materialsare presented below.

\section{Cement}

Cement used in this study was 53 grade Ordinary port land cement conforming to IS 12269:1987. The Physical andChemical properties are shown in Table 3.1 and 3.2.

Table 3.1: Cement properties.

\begin{tabular}{|c|c|}
\hline $\begin{array}{c}\text { Chemical } \\
\text { Composition }\end{array}$ & $\begin{array}{c}\text { Test Value } \\
(\mathbf{\%})\end{array}$ \\
\hline Silicon dioxide & 21.1 \\
\hline Calcium oxide & 62.4 \\
\hline Ferric oxide & 2.49 \\
\hline Aluminium oxide & 4.50 \\
\hline Loss on ignition & 2.40 \\
\hline
\end{tabular}

\begin{tabular}{|c|c|}
\hline Properties & Test Value \\
\hline Specific gravity & 3.14 \\
\hline Initial Setting time & $45 \mathrm{mins}$ \\
\hline Final Setting time & $230 \mathrm{~min}$ \\
\hline Consistency & $30 \%$ \\
\hline Fineness modulus & $6.5 \%$ \\
\hline
\end{tabular}


Table 3.2: Nano clay properties.

\begin{tabular}{|c|c|c|c|}
\hline Contents & Formula & Min.\% & Max.\% \\
\hline Silica & Sio2 & 45.00 & 47.00 \\
\hline Alumina & $\mathrm{Al} 203$ & 36.00 & 37.00 \\
\hline Ferric 0xide & Fe2o3 & - & 1 \\
\hline Calclum Oxide & Cao & - & 0.5 \\
\hline Magnesium Oxide & Mgo & - & 0.5 \\
\hline Tatinium Dioxide & Tio2 & - & 0.5 \\
\hline Loss On Ignition & - & 14 & 15 \\
\hline Potassium & K20 & - & 0.5 \\
\hline Sodium & Na20 & - & 0.5 \\
\hline Brightness & - & 78 & - \\
\hline Whiteness & - & 80 & - \\
\hline Acide Solubility & - & 1 & 2 \\
\hline Water Absorption & - & $36 \mathrm{Ml} / 100 \mathrm{Gm}$ & $38 \mathrm{Ml} / 100 \mathrm{Gm}$ \\
\hline Oil Absorption & - & $32 \mathrm{Ml} / 100 \mathrm{Gm}$ & $34 \mathrm{Ml} / 100 \mathrm{Gm}$ \\
\hline Moisture & - & 2 & 3 \\
\hline Ph Value@10\%Sol & - & 7 & 8 \\
\hline Bulk Density & - & $0.5 \mathrm{Gm} / \mathrm{Cc}$ & $0.6 \mathrm{Gm} / \mathrm{Cc}$ \\
\hline Retention On 500Mesh & - & - & 0.5 \\
\hline
\end{tabular}

\section{Nano clay}

Nano clays are nanoparticles of layered mineral silicates consisting of a two-dimensional, 1-nm thick layer with exceptional mechanical properties. The influence of Nano clay (NC) and calcined Nano clay (CNC) on the mechanical and thermal properties of cement Nano- composites present. Calcined Nano clay is prepared by heating Nano clay (Cloisite $30 \mathrm{~B}$ ) at $900^{\circ} \mathrm{C}$ for $2 \mathrm{~h}$. Characterization of microstructure is investigated using Quantitative $X$ - ray Diffraction Analysis (QXDA) and High-Resolution Transmission Electron Microscopy (HRTEM). The impact of partial substitution of cement with hydrophilic Nano clay platelets on the mechanical properties, workability, consistency, water absorption and morphology of cement mortar. Cement mortar mixtures with various replacement ratios, $1 \%$, and $10 \%$ of Nano clay by weight of cement, will be prepare and test according to the standards.

\section{Polypropylene Aggregates}

Polypropylene (PP) is a thermoplastic "addition polymer" made from the combination of propylene monomers. It is used in a variety of applications to include packaging for consumer products, plastic parts for various industries including the automotive industry, special devices like living hinges, and textiles Table 3.3, 3.4 \& 3.4.1 (Figure 3.4).

\section{Coarse Aggregates}

The sand collected conforming to IS: 383-2016. For
Table 3.3: Physical properties of the polypropylene used.

\begin{tabular}{|c|c|}
\hline Property & Value \\
\hline Tensile Strength & $32 \mathrm{MPa}(4700 \mathrm{PSI})$ \\
\hline Flexural Strength & $41 \mathrm{MPa}(6000 \mathrm{PSI})$ \\
\hline Fineness modulus & 4.2 \\
\hline Specific gravity & 0.91 \\
\hline Unit weight & 0.895 and $0.92 \mathrm{~g} / \mathrm{cm}^{3}$ \\
\hline
\end{tabular}

Table 3.4: Properties of Coarse Aggregate.

\begin{tabular}{|l|l|}
\hline \multicolumn{1}{|c|}{ Properties } & $\begin{array}{l}\text { T } \text { e } \mathbf{~ t ~} \\
\text { Values }\end{array}$ \\
\hline Specific gravity & 2.69 \\
\hline Water absorption & $1 \%$ \\
\hline Max Size of aggregate & $12.5 \mathrm{~mm}$ \\
\hline
\end{tabular}

Table 3.4.1: Sieve analyses of Polypropylene aggregates.

\begin{tabular}{|c|c|c|c|c|}
\hline $\begin{array}{c}\text { Size of } \\
\text { Sieve }\end{array}$ & $\begin{array}{c}\text { Mass of PP } \\
\text { Retaind } \\
\text { (gms) }\end{array}$ & $\begin{array}{c}\text { \% OF } \\
\text { Mass at PP } \\
\text { Retained }\end{array}$ & $\begin{array}{c}\text { Cumulative \% } \\
\text { Retrained (C) }\end{array}$ & $\begin{array}{c}\text { Cumulative } \\
\text { \% Retrained } \\
\text { N=100-C }\end{array}$ \\
\hline $4.75 \mathrm{MM}$ & 0.705 & 4.0 & 40.03 & 59.97 \\
\hline $2.36 \mathrm{MM}$ & 0.705 & 40 & 30.26 & 29.97 \\
\hline $1.18 \mathrm{MM}$ & 0.388 & 22 & 22.03 & 7.07 \\
\hline $600 \mathrm{UM}$ & 0.076 & 4.3 & 4.315 & 2.755 \\
\hline 300UM & 0.030 & 1.7 & 1.703 & 1.052 \\
\hline 150UM & 0.016 & 0.9 & 0.908 & 0.144 \\
\hline 75UM & 0.007 & 0.4 & 0.225 & 0.003 \\
\hline PAN & 0.006 & 0.38 & 0.019 & 0 \\
\hline
\end{tabular}

$D 10=1.3 D 30=1 \quad D 60=2.08$ Co-Efficient of Uniformity $C v=D 60 /$ $D 10=1.6$ Co-Efficient Of Curvature Ce $=D 302 / D 10 * D 60=1.198$

Citation: Kommisetti Komal ${ }^{1 \star}$, V.Swamy Srinath ${ }^{2}$, Feasibility of nano clay and polypropylene aggregates in self compacting concrete.

Op Acc J Bio Sci \& Res 9(1)-2021 

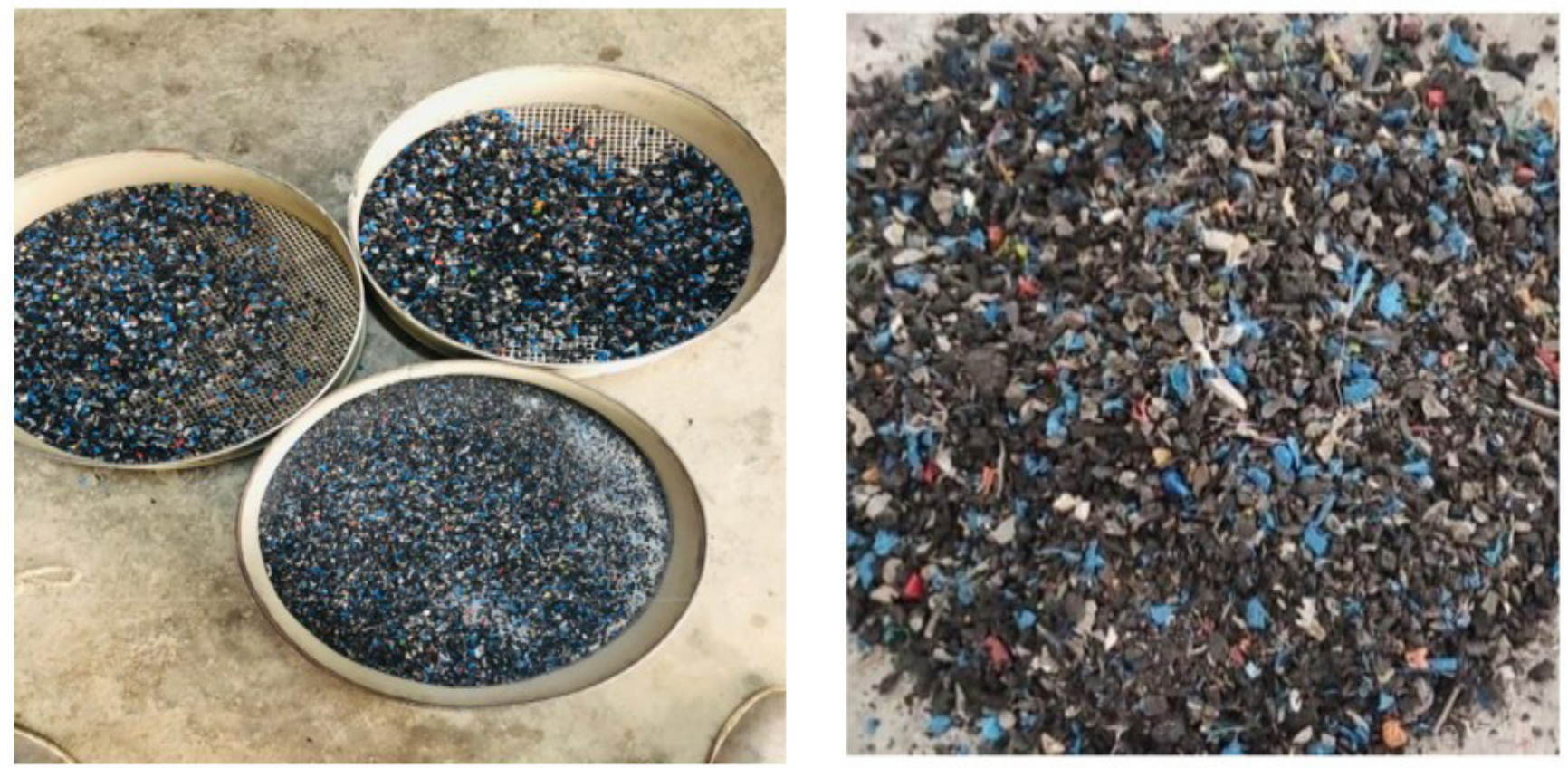

Figure 3.4: Polypropylene aggregates.

coarse aggregate, the parent rock is crushed through mini jaw crusher. During the crushing, we tried to maintain the maximum size of the aggregate. Aggregate with grain sizes above $4.75 \mathrm{~mm}$ is termed as coarse aggregate and below $4.75 \mathrm{~mm}$ is called as fine aggregate. The physical properties of the fine aggregate and the coarse aggregate are evaluated according to IS: 2386 (Part III)-1963.

Fineness Modulus of Coarse aggregate:

Weight of coarse aggregate sample taken $=5000 \mathrm{~g}$.

Fineness modulus of coarse aggregate $=656.88 / 100=6.56$

\section{Super Plasticizer}

Conplast SP430 was a chloride free, super plasticising admixture based on selected sulphonated naphthalene polymers. It is supplied as a brown solution which instantly disperses in water. Conplast SP430 disperses the fine particles in the concrete. mix, enabling the water content of the concrete to perform. CONPLAST SP 430 admixture also strikes the perfect balance between Workability retention and setting characteristics to provide efficiency in placing and finishing of the concrete.

Table 3.5: Fineness modulus of coarse aggregate.

\begin{tabular}{|c|c|c|c|c|}
\hline $\begin{array}{c}\text { IS Sieve } \\
\text { size }\end{array}$ & $\begin{array}{c}\text { Aggregate weight } \\
\text { retained in grams }\end{array}$ & $\begin{array}{c}\text { Weight of cumulative } \\
\text { Aggregate retained in } \\
\text { grams }\end{array}$ & $\begin{array}{c}\text { Percentage of } \\
\text { cumulative weight } \\
\text { retained }\end{array}$ & $\begin{array}{c}\text { Percentage of } \\
\text { Passing }\end{array}$ \\
\hline $40 \mathrm{MM}$ & 0 & 0 & 0 & 100 \\
\hline $20 \mathrm{MM}$ & 0.032 & 0.032 & 0.64 & 99.36 \\
\hline $10 \mathrm{MM}$ & 2.986 & 3.018 & 60.36 & 39.64 \\
\hline $4.75 \mathrm{MM}$ & 1.812 & 4.83 & 96.6 & 3.4 \\
\hline $2.36 \mathrm{MM}$ & 0.144 & 4.974 & 99.48 & 0.52 \\
\hline $1.18 \mathrm{MM}$ & 0.016 & 4.99 & 99.8 & 0 \\
\hline $600 \mu$ & 0.001 & 5 & 100 & 0 \\
\hline $300 \mu$ & 0 & 5 & 100 & 0 \\
\hline $150 \mu$ & 0 & 5 & 100 & \\
\hline
\end{tabular}

Citation: Kommisetti Komal ${ }^{1 *}$, V.Swamy Srinath ${ }^{2}$, Feasibility of nano clay and polypropylene aggregates in self compacting concrete. Op Acc J Bio Sci \& Res 9(1)-2021 
Results and Discussions

Shown in Figures Slump Flow test, L-Box test, V-Funnel test and J-Ring test Results

Table 4: Slump Flow test, L-Box test, V-Funnel test and J-Ring test Results.

\begin{tabular}{|c|c|c|c|c|c|}
\hline \multirow[b]{2}{*}{ S.No } & $\begin{array}{c}\text { Samples (\%) (N.C-P. } \\
\text { FA) }\end{array}$ & $\begin{array}{l}\text { Slump flow test } \\
\text { mm }\end{array}$ & $\begin{array}{c}\text { L-box test (H2/ } \\
\text { H1) }\end{array}$ & $\begin{array}{l}\text { V-funnel test in } \\
\text { seconds }\end{array}$ & $\begin{array}{c}\text { J-ring test in } \\
\text { mm }\end{array}$ \\
\hline & \multirow[b]{2}{*}{ SCC M30(0-0-0) } & \multirow[b]{2}{*}{738} & \multirow[b]{2}{*}{0.89} & \multirow[b]{2}{*}{10} & \multirow[b]{2}{*}{2} \\
\hline 1 & & & & & \\
\hline 2 & M-1 (2-5) & 733 & 0.87 & 10 & 2 \\
\hline 3 & $M-2(2-10)$ & 735 & 0.85 & 9 & 3 \\
\hline 4 & M-3 (2-15) & 739 & 0.86 & 8 & 4 \\
\hline 5 & $M-4(2-20)$ & 742 & 0.86 & 8 & 4 \\
\hline 6 & M-5 (2-25) & 748 & 0.84 & 7 & 3 \\
\hline 7 & M-6 (2-30) & 743 & 0.8 & 7 & 5 \\
\hline 8 & M-7 (5-5) & 732 & 0.87 & 9 & 2 \\
\hline 9 & M-8 (5-10) & 734 & 0.86 & 9 & 3 \\
\hline 10 & M-9 (5-15) & 737 & 0.86 & 9 & 3 \\
\hline 11 & M-10 (5-20) & 745 & 0.83 & 8 & 5 \\
\hline 12 & M-11 (5-25) & 743 & 0.83 & 8 & 5 \\
\hline 13 & $M-12(5-30)$ & 741 & 0.81 & 7 & 6 \\
\hline
\end{tabular}

Table 5: Cube Compressive Strength of M30 Grade Concrete and Prism Flexural Strength of M30 Grade Concrete.

\begin{tabular}{|c|c|c|c|}
\hline & \multicolumn{2}{|c|}{$\begin{array}{c}\text { Compressive Strength } \\
\text { (MPa) }\end{array}$} & $\begin{array}{c}\text { Flexural Strength } \\
\text { (Mpa) }\end{array}$ \\
$\begin{array}{c}\text { Concrete Mix } \\
\text { (N.C \% - PP. FA \%) }\end{array}$ & 7 Days & 28 Days & for 28 Days \\
\hline Control Concrete & 26.89 & 42.67 & 5.02 \\
\hline M-1(2-5) & 26.19 & 41.79 & 4.8 \\
\hline M-2 (2-10) & 25.48 & 40.6 & 4.6 \\
\hline M-3 (2-15) & 24.23 & 39.32 & 4.52 \\
\hline M-5 (2-25) & 24.38 & 36.22 & 3.8 \\
\hline M-6 (2-30) & 23.26 & 35.19 & 3.6 \\
\hline M-7(5-5) & 26.05 & 41.56 & 3.2 \\
\hline M-8 (5-10) & 25.81 & 40.1 & 4.8 \\
\hline M-9 (5-15) & 25.68 & 39.52 & 4.5 \\
\hline M-10(5-20) & 24.45 & 37.11 & 3.7 \\
\hline M-11(5-25) & 23.87 & 35.83 & 3.8 \\
\hline M-12(5-30) & 23.13 & 35.56 & 3.9 \\
\hline
\end{tabular}

Citation: Kommisetti Komal ${ }^{1 \star}$, V.Swamy Srinath², Feasibility of nano clay and polypropylene aggregates in self compacting concrete.

Op Acc J Bio Sci \& Res 9(1)-2021 

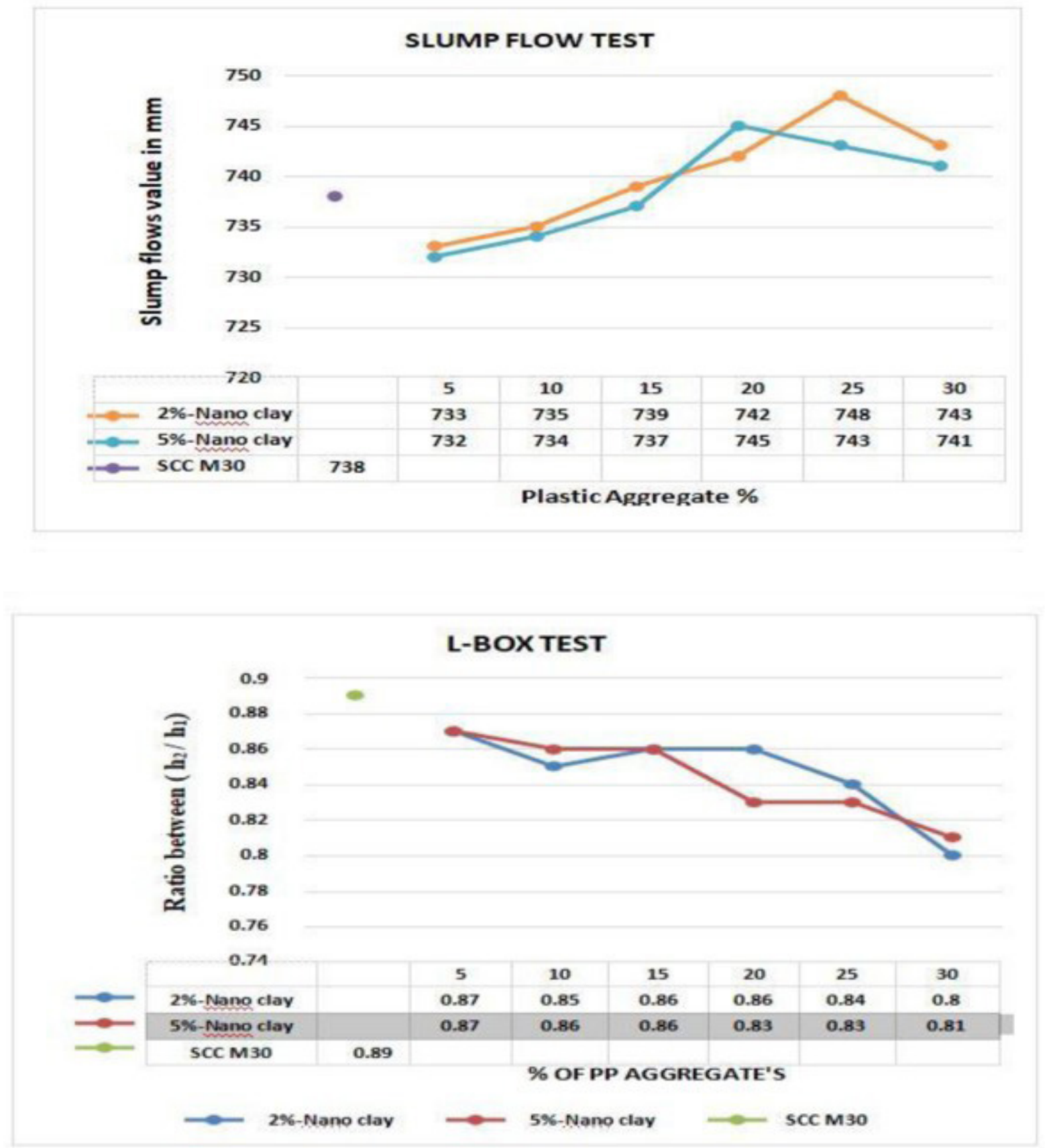

Citation: Kommisetti Komal ${ }^{1 *}$, V.Swamy Srinath², Feasibility of nano clay and polypropylene aggregates in self compacting concrete. Op Acc J Bio Sci \& Res 9(1)-2021 

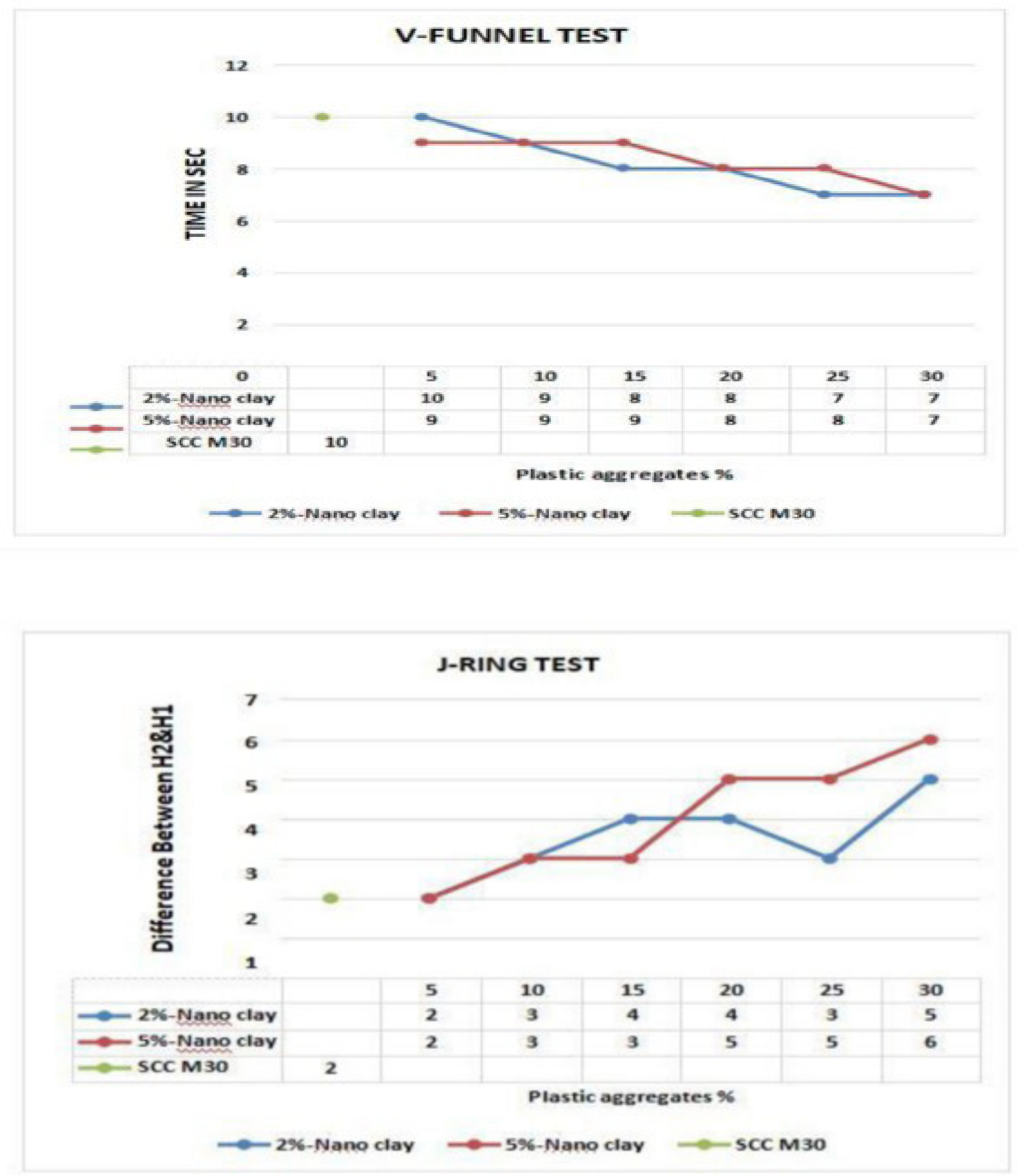

Citation: Kommisetti Komal ${ }^{1 *}$, V.Swamy Srinath ${ }^{2}$, Feasibility of nano clay and polypropylene aggregates in self compacting concrete.

Op Acc J Bio Sci \& Res 9(1)-2021 

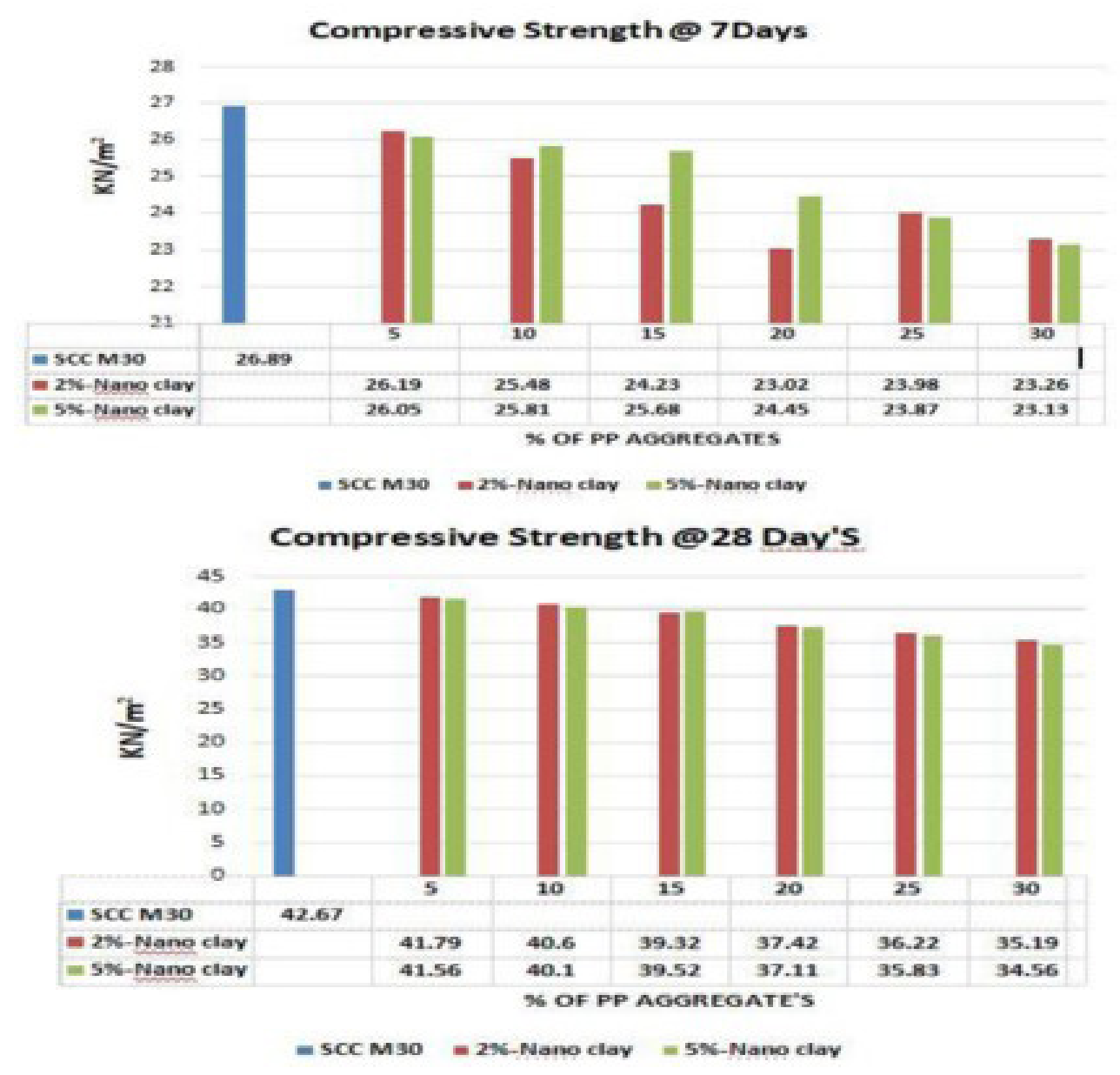

Figures: Slump Flow test, L-Box test, V-Funnel test and J-Ring test Results.

\section{Conclusions}

The combined effect of nano clay and polypropylene aggregates on the rheological properties and compressive strength of the self-compacting concrete are experientially evaluated for SCC M30 grade based on IS10262-2016.the following are the conclusions written by investigation.

a) Rheological properties all obey the conformity criteria of SCC based on European Federation of National Associations Representing for Concrete (EFNARC 2016).

b) The slump flow of all samples within the slump flow classSF2.v-funnel values of the samples within the class of VF2.and the L-BOX values also with in the PA2.

c) The compressive strength of SCC with polypropylene aggregates lower than the normal SCC with polypropylene aggregates.

d) The segregation was playing more key role in the polypropylene aggregate added to the SCC. That the reason we limited the replacement of polypropylene aggregate up to $30 \%$ volume of the fine aggregates.

e) At 7-days Concrete of SCC M-30 grade. Replacement used $5 \%$ to $30 \%$ in pp- aggregate and $2 \%$ of nano clay with a $5 \%$ increment; at 5\%, strength decreases 2.61 percent, and at $30 \%$, strength decreases 13.49 percent.

f) At 7-days Concrete of SCC M-30 grade. Replacement used $5 \%$ to $30 \%$ in pp-aggregate and $5 \%$ of nano clay with a $5 \%$ increment; at 5\%, strength decreases 3.12 percent, and at 30\%, strength decreases 13.98 percent.

g) At 28-days Concrete of SCC M-30 grade. Replacement used $5 \%$ to $30 \%$ in pp- aggregate and

h) $2 \%$ of nano clay with a $5 \%$ increment; at $5 \%$, strength decreases 2.06 percent, and at 30\%, strength decreases 17.52 percent.

i) At 28-days Concrete of SCC M-30 grade. Replacement used $5 \%$ to $30 \%$ in pp- aggregate and $5 \%$ of nano clay with a $5 \%$ increment; at $5 \%$, strength decreases

Citation: Kommisetti Komal ${ }^{1 *}$, V.Swamy Srinath ${ }^{2}$, Feasibility of nano clay and polypropylene aggregates in self compacting concrete.

Op Acc J Bio Sci \& Res 9(1)-2021 
2.60 percent, and at 30\%, strength decreases 19.01 percent.

j) Up to $30 \%$ of the polypropylene aggregates restriction to gets the smooth surface of the SCC. more than $30 \%$ of polypropylene aggregate's used in the concrete the top surface does not get uniformly. That is the reason we use only $30 \%$ of polypropylene aggregates.

k) All the fresh properties of sample mixers within the limits of the European federation of national associations representing for concrete \{EFNARC 2016\}.

\section{Scope of the Work}

This work can do the shear Box test in the future. and finding the rheological property was perfect. In case the ratios of the Nano clay and pp aggregate also changed to get the properties of the mix within the 1-5\%. The Nano clay percentage was $0-5 \%$ and get the mix was individual ratios of $1 \%, 3 \%, 4 \%$ respectively.

\section{References}

1. Payam Hosseini, Alireza Afshar, Bijan Vafaei, Abbas Booshehrian, Elias Molaei Raisi, et al. (2015) Effects of nano-clay particles on the shortterm properties of self- compacting concrete, European Journal of Environmental and Civil Engineering.

2. Rabar H Faraja, Aryan Far H. Sherwanib, Ako Daraeib (2015) Mechanical, fracture and durability properties of self-compacting high strength concrete containing recycled polypropylene plastic particles.

3. Saeid Hesami, Iman Salehi Hikouei, Seyed Amir Ali Emadi (2016) Mechanical behavior of self-compacting concrete pavements incorporating recycled tire rubber crumb and reinforced with polypropylene fiber.

4. Arash Karimipoura, Mansour Ghalehnovib, Jorge de Britoc, Mohammad Attarid (2016) The effect of polypropylene fibres on the compressive strength, impact and heat resistance of self-compacting concrete.

5. Sheelan M. Hama, Nahla N. Hilal; Fresh properties of self-compacting concrete with plastic waste as partial replacement of sand.

6. Dominic Stefan Law Yim Wan, Farhad Aslani, M.ASCE, Guowei Ma (2016) Lightweight Self-Compacting Concrete Incorporating Perlite, Scoria, and Polystyrene Aggregates.

7. Bala Rama Krishna Chunchu (2018) Fresh and hardened properties of self-compacting concrete fine aggregate replacing with high polypropylene aggravates ; International Journal of Civil Engineering and Technology (IJCIET) 9(12): 831-838.

8. Article ID IJCIET_09_12_086.

*Corresponding author: KOMMISETTI KOMAL, Email: kommisettykomal@gmail.com

Next Submission with BGSR follows:

- Rapid Peer Review

- Reprints for Original Copy

- E-Prints Availability

- Below URL for auxiliary Submission Link: https://biogenericpublishers.com/submit-manuscript/ 